\title{
Time: A Major Thematic Study of Shakespeare's Sonnets
}

\author{
Yongkun Wan \\ (Yuxi Teachers College, Yuxi Municipality in Yunnan Province of China 653100) \\ wanyongkun123@163.com
}

(Yuxi Teachers College, Yuxi Municipality of Yunnan Province 653100)

\section{Keywords: Shakespeare; Sonnets; Time; Major Themes}

\begin{abstract}
Shakespeare wrote 154 sonnets during all his life. These sonnets are actually the thematic expression of his unique experience and thinking of time. Shakespeare not only describes time's ruthless consumption of beauty and love, but also displays that he has done all his efforts to surpass time and preserve immortality with two solutions, thus the most outstanding result of his philosophical thinking of time is that his bionomy and poetics comes into being.

The word "time" is directly used about 86 times in the sonnets, among which most occurs in the capitalized form "Time"[1]. Moreover, some words showing time concept can be frequently found in Shakespeare's sonnets: "day", 46 times; "hour", 16 times; "spring", 6 times; "summer", 20 times; "autumn", 2 times; "winter", 10 times; etc. Shakespeare describes time as a "bloody tyrant" (Sonnet 16), "devouring" and "swift-footed" (Sonnet 19), "injurious hand" and "age's cruel knife" (Sonnet 63). Time is often personified and appears capitalized, like in a name, in some sonnets. Time is making Shakespeare old and near "hideous night" (Sonnet 12) or death, and time will eventually rob the beauty of the young man. Shakespeare presents time as the protagonist and aggressor throughout his sonnets[2].
\end{abstract}

Shakespeare begins his sonnets by introducing six of his most important themes-beauty, time, decay, immortality, procreation and selfishness, which are interrelated in sonnet 1 both thematically and through the use of images associated with business or commerce[3]. In sonnet 2 , time again is the great enemy, besieging the youth's brow, digging trenches and wrinkles in his face, and ravaging his good looks. Sonnet 5 compares nature's four seasons with the stages of the young man's life. Although the seasons are cyclical, his life is linear, and hours become tyrants that oppress him because he cannot escape time's grasp. Time might "frame/The lovely gaze where every eye doth dwell", meaning that everyone notices the youth's beauty, but time's "never-resting" progress ensures that this beauty will finally fade. In Sonnet 19, the poet addresses time and, using vivid animal imagery, comments on time's normal effects on the nature [4].

Sonnet 60 is one of the most famous of the sonnets and perhaps the best exemplar of the subject of time's ravages because it deals with the universal concerns of time and its passing and ravages[5]. Each quatrain engages the time theme in a unique way, with the destructive force of time redoubling with each successive line, which is prevalent throughout the sonnets, and it takes many different forms (or concrete images), sometimes referring to the destructive power of time in general, other times focusing on the effects of time on a specific character in the sonnets such as the poet or the young man. Sonnet 73 is almost as exemplary as sonnet 60 in expressing the time theme. The sonnet focuses on the poet's own anxiety over growing old and, like sonnet 60, each quatrain takes up the time theme in a unique way, comparing the poet's "time of year" (i.e., stage of life) with various examples of the passing of time in the nature.

Shakespeare is hauntingly preoccupied with the passing of time and everything that it entails, including mortality, memory, inevitability, and change[6]. Although he is distressed over such things that he has no control over, he devotes much of his writing in the sonnets how to fight a great and vain battle against time itself with two kinds of choices: breed and verse.

The first seventeen sonnets propose one method by which Shakespeare feels time can be fought[7]. He urges the young man to have children so that his beauty will be preserved in posterity and therefore time will not have won the battle. Sonnet 1 opens not only the entire sequence of 
sonnets, but also the first mini-sequence, a group comprising the first seventeen sonnets, often called the procreation sonnets because they each urge the young man to bear children as an act of defiance against time. In sonnet 2 , beauty is conceived of as a treasure that decays unless, through love, its natural increase-marrying and having children-is made possible. As usual, in sonnet 7 , the poet argues that the only way for the youth to ensure that he is remembered after he dies is to have a child, making it clear that this child should be a son. Sonnet 8 compares a single musical note to the young man and a chord made up of many notes to a family. In sonnet 11, the poet argues that the young man needs to have a child in order to maintain a balance in nature, for as the youth grows old and wanes, his child's "fresh blood" will act as a balance to his own old age. Sonnet 12 again speaks of the sterility of bachelorhood and recommends marriage and children as a means of immortality. Additionally, the sonnet gathers the themes of Sonnets 5, 6, and 7 in a restatement of the idea of using procreation to defeat time. This final point, that having children is the single means of gaining immortality, is most strongly stated in the sonnet's concluding couplet: "And nothing 'gainst Time's scythe can make defense/Save breed, to brave him when he takes thee hence"; In these lines, "Time's scythe", a traditional image of death, is unstoppable "save breed", meaning except by having children. Sonnet 13 furthers stating that death will forever vanquish the young man's beauty if he dies without leaving a child.

After Sonnet 17, when it seems apparent that the young man is unwilling to marry, Shakespeare presents another way in which to wage war against tyrannous time[8]. He says that his verse will always exist and be read and that if the young man is not alive in his posterity, through his verse his love will be forever alive. Sonnet 18 is the first poem in the sonnets not to vividly persuade the young man to have children. The procreation sequence of the first 17 sonnets ended with the speaker's realization that the young man might not need children to preserve his beauty; he could also live, the poet writes at the end of Sonnet 17, "in my rhyme". Sonnet 18, then, is indeed the poet's first attempt to preserve the young man's beauty for all time. An important theme of the sonnet (as it is an important theme throughout much of the sequence) is the power of the speaker's poem to defy time and last forever, carrying the beauty of the beloved down to future generations. The beloved's "eternal summer" shall not fade precisely because it is embodied in the sonnet: "So long as men can breathe or eyes can see", the speaker writes in the couplet, "So long lives this, and this gives life to thee". Sonnet 19 commands time not to age the young man and concludes by boldly asserting that the poet's own creative talent will make the youth permanently young and beautiful. In sonnet 21 , not only does the poet grant the youth immortality through his verse, but because his enduring love is repeatedly stressed as well, the poet himself gains a kind of immortality. Likening himself to a distiller, the poet of sonnet 54, who argues that his verse distills the youth's beauty, or "truth" sees poetry as a procreative activity: Poetry alone creates an imperishable image of the youth. Sonnet 55, one of Shakespeare's most famous verses, asserts the immortality of the poet's sonnets to withstand the forces of decay over time, and continues this from the previous sonnet, in which the poet likened himself to a distiller of truth. In the couplet of sonnet 60, Shakespeare then stunningly declares that he has found a way to confound time: his verse, despite time's "cruel hand", will live on, and continue to praise the worth of the beloved. This is the often-invoked corollary to time's passage: the poet, disappointed that the young man will not defy time by having children, writes sonnet after sonnet about the mighty power of the "bloody tyrant" time, then declares that his poems will remain immortal, and will enable the young man's beauty to live forever. Quatrain three of sonnet 116 holds that love's undying essence prevailing against the "bending sickle" of time. Time's "hours and weeks" are "brief" compared to love's longevity, and only some great and final destruction of apocalyptic proportions could spell its doom.

At the same time, it is rather interesting and noticeable for us that at times Shakespeare's attitudes about breed and verse are not always constant throughout the sonnets[9]. Sonnet 15 also introduces another major theme that will be more greatly developed in later sonnets: the power of the poet's verse to memorialize forever the young man's beauty. "I ingraft you new", the poet says 
at the end of the sonnet, by which the poet implies that, however steady is the charge of decay, his verses about the young man will keep the youth's beauty always fresh, always new; the sonnets immortalize this beauty. Sonnet 16 continues the arguments for the youth to marry and at the same time now disparages the poet's own poetic labors, for the poet concedes that children will ensure the young man immortality more surely than his verses will because neither verse nor painting can provide a true reproduction of the "inward worth" or the "outward fair" of the youth. In Sonnet 17, in which the poet fears that his praise will be remembered merely as a "poet's rage" that falsely gave the youth more beauty than he actually possessed, thus expressing an insecurity about his poetic creations that began in the preceding sonnet. The sonnet's concluding couplet links sexual procreation and versification as parallel activities: "But were some child of yours alive that time,/You should live twice-in it and in my rime". The poet's task is an endless struggle against time, whose destructive purpose can only be frustrated by the creation of fresh beauty or art, which holds life suspended. Although the poet of sonnet 60 seems certain that time's destruction is inevitable, he is clearly no longer concerned that the young man has a child to ensure the immortality of his beauty. Now, the poet's own sonnets are the only security the youth needs to gain eternal worth.

In conclusion, whether explicit or implicit, it is no doubt that time is a prevalent theme throughout Shakespeare's 154 sonnets as a whole[10]. Time uncontrollably flies forever, and beauty and love will inevitably decay one day with time's passing. Time is the enemy; Time is Death. In order to shrug off time's cruel ravages, surmount time's powerful restriction and seek to immortality of beauty and love, Shakespeare turns to breed and verse. The solution of procreation is really the poet's well-meaning persuasion in the first seventeen sonnets. Since sonnet 18, due to the young man's unwillingness to get married and have children, the poet appears to have abandoned breed solution in favor of another: his versification. The poet's sonnets serve the same purpose as a son whom the poet wants the young man to father because they perpetuate the youth's beauty just as a son would. In fact, the sonnets are even more immortal than a son. The sonnets continue to be read even today, whereas the young man's progeny may have completely died out. Nowadays, Shakespeare's sonnets have been receiving high praise for their exquisite wording and imagery and for their refusal to stoop to sentimentality, and thus time witnesses these sonnets' immortality just as he boasts.

\section{References}

[1] B.K. Huang: Selected Readings in Shakespeare(Peking University Press, China 2005), p.1-318.

[2] M.Q. Li: Shakespeare's Sonnets(Yunnan University Press, China 2008), p.1-336.

[3] N.C. Chen: The Theme of Time in Shakespeare's Sonnets(In Chinese), Foreign Language (Journal of Shanghai Foreign Languages University). 80(1992)No.4, p.45-48.

[4] D. Wu: On the Time Theme of Shakespeare's Sonnets(In Chinese), Foreign Literature Review. 16(2002)No.3, p.88-93.

[5] Q.Y. Wu and J.F. Ge: Time in Shakespeare's Sonnets(In Chinese), Journal of Wenzhou Normal College. 24(2003)No.1, p.62-66.

[6] Y.M. Luo: The Sickle of Time: a Study of the Theme in Shakespeare's Sonnets(In Chinese), World Literature Review. 16(2007)No.1, p.283-284.

[7] Y.G. Shen and Z.S. Li: To Say What is "Not to Say"-An Analysis of the Theme in Shakespeare's Sonnets(In Chinese), Journal of HebeiUniversity(Philosophy and Social Science) . 38(2013)No.3, p.134-138.

[8] J. Wu: Interpretation of the Time Theme of Shakespeare's Sonnets(In Chinese), Science and Technology Information. 66(2011)No.31, p.344-345.

[9] H.L. Li: Eternity under the Sickle of Time-the Theme of Time in Shakespeare's Sonnets(In Chinese), Science and Technology Information. 26(2009)No.4, p.441-442.

[10]J. Zhang: The Great Shakespeare: a Eternal Theme: A Literature Review of Researches on the Themes of Shakespeare's Sonnets(In Chinese), Foreign Language and Literature(bimonthly) . 30(2014)No.1, p.44-47. 